Rafael Cantón ${ }^{1,2}$

José Barberán ${ }^{3}$

Manuel Linares ${ }^{4}$

José María Molero ${ }^{5}$

José Miguel Rodríguez-

González-Moro ${ }^{6}$

Miguel Salavert ${ }^{7}$

Juan González del Castillo8

\section{Decalogue for the selection of oral antibiotics for lower respiratory tract infections}

\begin{abstract}
${ }^{1}$ Servicio de Microbiología. Hospital Universitario Ramón y Cajal and Instituto Ramón y Cajal de Investigación Sanitaria (IRYCIS). Madrid. Spain.

${ }^{2}$ CIBER de Enfermedades Infecciosas. Instituto de Salud Carlos III. Madrid. Spain.

${ }^{3}$ Servicio de Medicina Interna y Enfermedades infecciosas, Hospital Universitario HM Monteprincipe, Universidad San Pablo CEU. Madrid, Spain.

${ }^{4}$ Servicio de Microbiologia Clínica, Hospital Universitario Príncipe de Asturias, Madrid, Spain.

${ }^{5}$ Centro de Salud San Andrés. Medicina de Familia, Servicio Madrileño de Salud, Madrid, Spain.

${ }^{6}$ Servicio de Neumología. Hospital Universitario Príncipe de Asturias, Alcalá de Henares, Spain

${ }^{7}$ Unidad de Enfermedades Infecciosas. Área Clínica Médica, Servicio de Medicina Interna, Hospital Universitario y Politécnico La Fe and Instituto de Investigación Sanitaria La Fe (IIS La Fe), Valencia, Spain.

${ }^{8}$ Servicio de Urgencias, Hospital Clínico San Carlos and Instituto de Investigación Sanitaria San Carlos (IdISSC), Madrid, Spain
\end{abstract}

Article history

Received: 30 December 2021; Accepted:12 January 2022; Published: xx January 2022

\begin{abstract}
Lower respiratory tract infections, including chronic obstructive pulmonary disease exacerbations (COPD-E) and community acquired pneumonia (CAP), are one of the most frequent reasons for consultation in primary care and hospital emergency departments, and are the cause of a high prescription of antimicrobial agents. The selection of the most appropriate oral antibiotic treatment is based on different aspects and includes to first consider a bacterial aetiology and not a viral infection, to know the bacterial pathogen that most frequently cause these infections and the frequency of their local antimicrobial resistance. Treatment should also be prescribed quickly and antibiotics should be selected among those with a quicker mode of action, achieving the greatest effect in the shortest time and with the fewest adverse effects (toxicity, interactions, resistance and/or ecological impact). Whenever possible, antimicrobials should be rotated and diversified and switched to the oral route as soon as possible. With these premises, the oral treatment guidelines for mild or moderate COPD-E and CAP in Spain include as first options betalactam antibiotics (amoxicillin and amoxicillin-clavulanate and cefditoren), in certain situations associated with a macrolide, and relegating fluoroquinolones as an alternative, except in cases where the presence of Pseudomonas aeruginosa is suspected.
\end{abstract}

Keywords: respiratory tract infections; bacterial infections; oral treatment; antibiotic use; antimicrobial resistance

Correspondence:

Rafael Cantón.

Servicio de Microbiologia. Hospital Universitario Ramón y Cajal and Instituto Ramón y Cajal de Investigación Sanitaria (IRYCIS). Madrid. Spain.

E-mail: rafael.canton@salud.madrid.org

Juan Gonzalez del Castillo.

Servicio de Urgencias, Hospital Clínico San Carlos and Instituto de Investigación Sanitaria San Carlos (IdISSC), Madrid, Spain.

E-mail: jgonzalezcast@gmail.com

\section{Decálogo para la selección del antibiótico oral en las infecciones respiratorias de vías bajas}

\section{RESUMEN}

Las infecciones del tracto respiratorio inferior, incluyendo las exacerbaciones de la enfermedad pulmonar obstructiva crónica (EPOC) y la neumonía adquirida en la comunidad (NAC), son uno de los motivos de consulta más frecuentes en atención primaria y los servicios de urgencias hospitalarios, y son la causa de una elevada prescripción de antimicrobianos. La selección del tratamiento oral más adecuado con antibióticos se basa en diferentes aspectos e incluye considerar en primer lugar una etiología bacteriana y no una infección vírica, conocer los patógenos bacterianos que más frecuentemente causa estas infecciones y la frecuencia local de su resistencia antimicrobiana. Además, el tratamiento debe prescribirse rápidamente y los antibióticos deben seleccionarse entre los que tienen un modo de acción más rápido, logrando el mayor efecto en el menor tiempo y con el menor número de efectos adversos (toxicidad, interacciones, resistencia y/o impacto ecológico). Siempre que sea posible, hay que rotar y diversificar los antimicrobianos y pasar a la vía oral lo antes posible. Con estas premisas, las guias de tratamiento oral de la exacerbación leve o moderada de la EPOC y NAC en España incluyen como primera opción los antibióticos betalactámicos (amoxicilina y amoxicilina-clavulánico y cefditoreno), en determinadas situaciones asociados a un macrólido, y relegando las fluoroquinolonas como alternativa, salvo en los casos en que se sospeche la presencia de Pseudomonas aeruginosa.

Palabras clave: infecciones del tracto respiratorio; infecciones bacterianas: tratamiento oral; uso de antimicrobianos; resistencia antimicrobiana, 


\section{INTRODUCTION}

Lower respiratory tract infections (LRTI) are one of the most frequent reasons for consultation in primary care and hospital emergency departments, and are the cause of a high prescription of antimicrobial agents [1-3]. It is therefore necessary to consider a series of premises that guide their choice, especially in cases in which the patient's situation allows oral treatment, since their follow-up will be performed on an outpatient basis. For this reason, a group of professionals from the fields of primary care, hospital emergency medicine, internal medicine, infectious diseases, pneumology and clinical microbiology have proposed a Decalogue that summarises the criteria that, as a priority, should be taken into account when choosing oral antimicrobial treatment in exacerbations of chronic obstructive pulmonary disease (COPD) and community-acquired pneumonia (CAP). Many of the aspects listed here have been previously reviewed in greater depth [4-8]. This Decalogue is based on published scientific evidence and the personal experience of the panel of the authors. The recommendations are aligned with the principles of the National Plan against Antimicrobial Resistance (PRAN) of the Spanish Agency of Medicines and Health Products (AEMPS), which aims, among other objectives, to improve the prescription of this group of drugs in order to reduce antimicrobial resistance (https://www.resistenciaantibioticos.es/es, accessed 30 December 2021).

\section{1.- IS THIS A BACTERIAL INFECTION?}

The most common cause of COPD exacerbation is bacterial infection of the tracheobronchial tree. However, there are other possible aetiologies such as virus, contamination, thromboembolism or heart failure and the cause is not known in a third of cases. Identifying the aetiology that causes this exacerbation is of great importance in order to establish appropriate treatment. It is also important to identify patients who can be safely treated without antibiotics and to optimise treatment for those who need it [9]. In CAP, the majority is of bacterial aetiology, although in almost two thirds of patients it may remain unidentified, either because of a lack of microbiological diagnosis or because insufficient methods are used to identify the pathogen [10].

To identify a bacterial aetiology as the cause of the exacerbation, markers such as C-reactive protein and procalcitonin have been described, but the systematic usefulness of their use in these cases has not been established and their use in real life is very restricted [9]. A meta-analysis suggests that procalcitonin may be useful in reducing antibiotic prescribing, without affecting the rate of treatment failure, length of hospitalisation, recurrence or mortality [11]. However, due to the methodological limitations, the evidence is still low to moderate, so a general recommendation for the use of this or any other biomarker to establish the bacterial aetiology of an exacerbation cannot be established. A similar situation occurs in patients with CAP, where procalcitonin may be more useful in those cases where serial determinations are performed and as a guide in reducing the duration of antimicrobial therapy $[12,13]$.

The classic Anthonisen criteria [14] for COPD exacerbation, based on clinical data of changes in symptomatology, increased dyspnoea, cough and sputum, and especially change in sputum colour, with all possible concerns, are still present in daily practice. The administration of antibiotics in COPD is more effective than placebo in exacerbations that meet at least two of the following three criteria: increased dyspnoea, sputum purulence or increased sputum volume. However, of

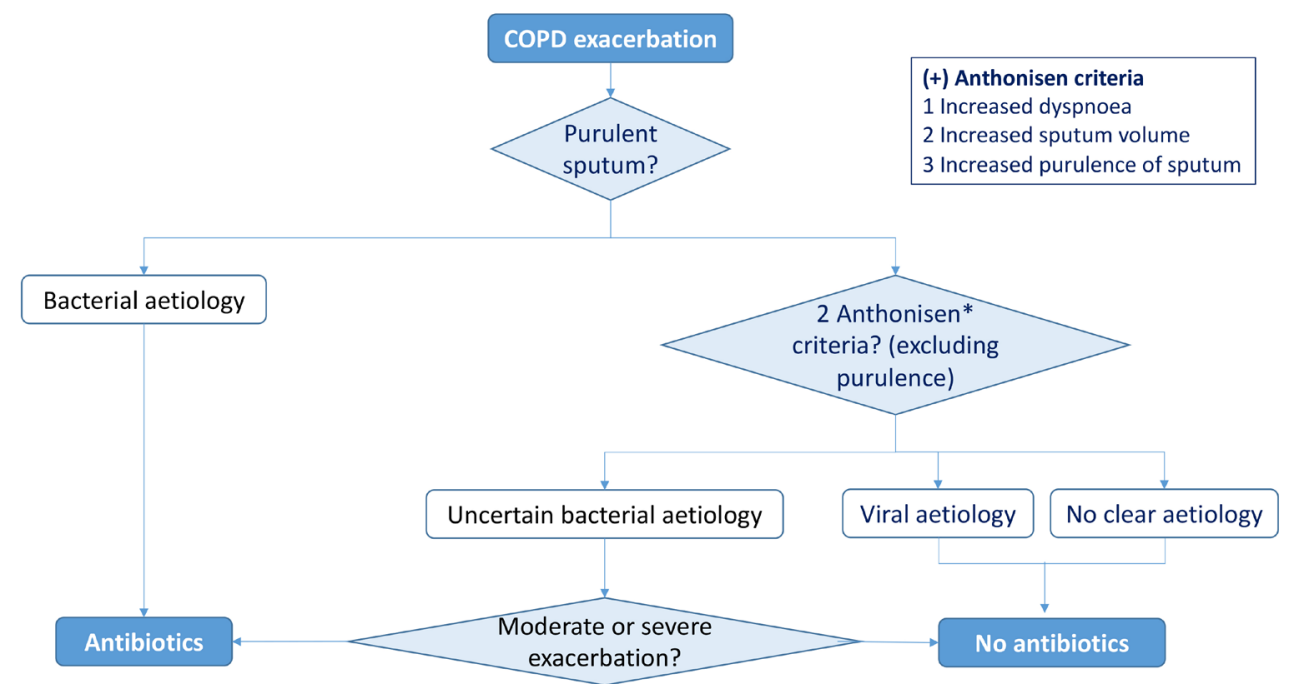

Figure $1 \quad$ Suspicion of bacterial infection in COPD exacerbation and decision of antimicrobial treatment [modified from reference 9] 

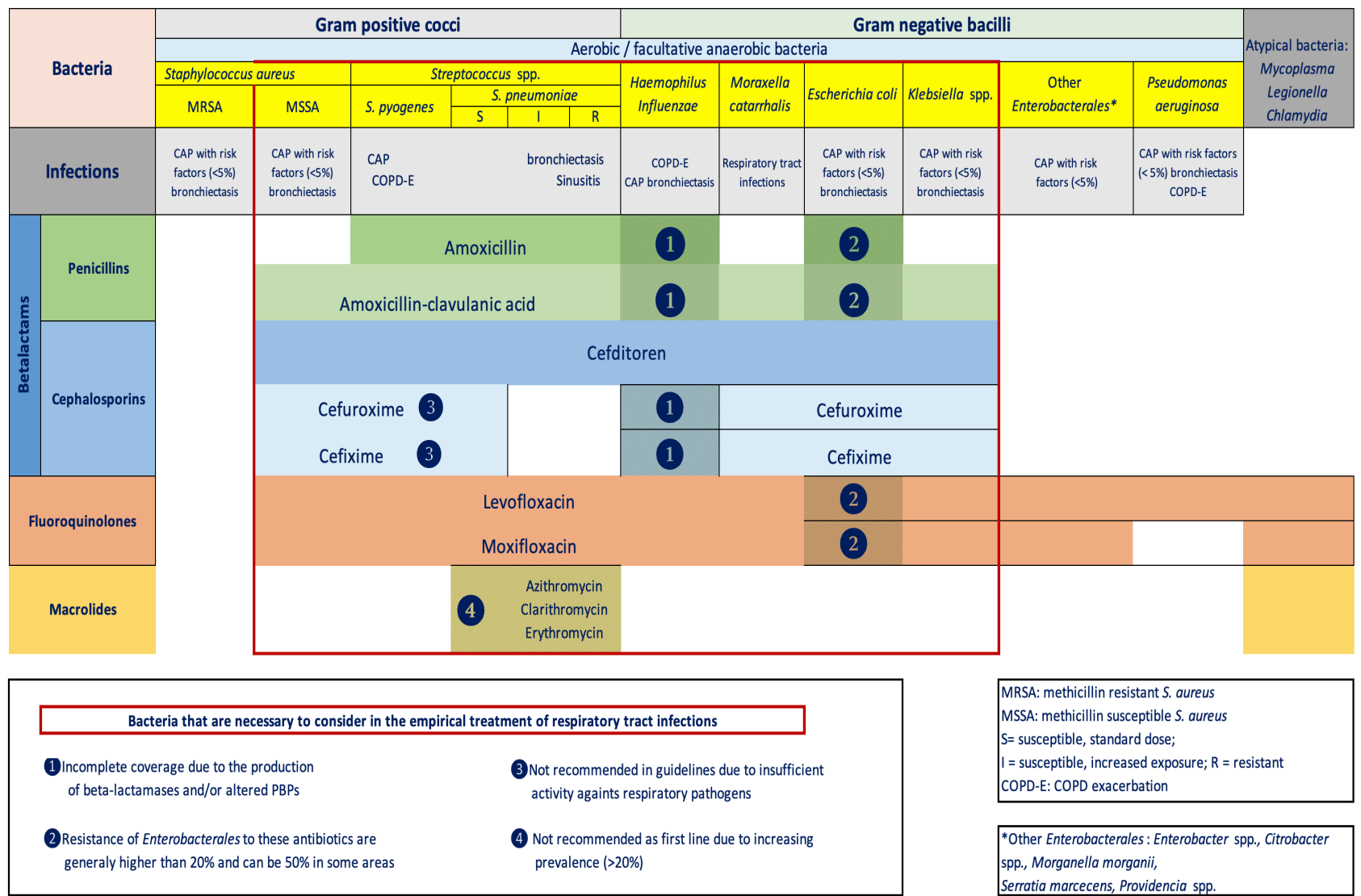

MRSA: methicillin resistant S. aureus MSSA: methicillin susceptible $S$. aureus $S=$ susceptible, standard dose; $I=$ susceptible, increased exposure; $R=$ resistant COPD-E: COPD exacerbation

Figure 2 Antimicrobial spectrum of the main oral antibiotics in the treatment of lower respiratory tract infections [modified from reference 4].

the three recommended criteria, the one that best predicts bacterial infection is the change in sputum colour and purulence $[14,15]$ (Figure 1). In contrast, mucous sputum is rarely associated with bacterial infection [17] and in these cases other causes must be considered. Antibiotics are particularly indicated in severe COPD exacerbations and in the presence of purulent sputum. Sputum analysis (Gram stain and culture) is only indicated in patients with severe or very severe exacerbations, in those with frequent exacerbations, bronchiectasis, need for ventilation or in case of antibiotic treatment failure.

In CAP the diagnostic criteria are based on radiological changes and respiratory symptoms such as cough, purulent sputum, dyspnoea and chest pain, as well as fever. In patients with criteria for hospitalisation, Gram stain and culture are recommended as a minimum when sputum is purulent and detection of Streptococcus pneumoniae and Legionella pneumophila antigen [18].

\section{2.- MOST LIKELY AETIOLOGY: MAXIMISING ERADICATION AND ADJUSTING SPECTRUM}

Microbiological diagnosis in COPD exacerbations and CAP is difficult to establish, even when complex and invasive diagnostic methods are used. Although the possible role of the usual microbiota in LRTIs, especially in COPD exacerbation, is currently being discussed, the focus is on the microorganisms traditionally associated with these infections. In CAP, the aetiology is usually monomicrobial. Globally, the most frequent agent is $S$. pneumoniae (20-65\%) [19] and should always be taken into account when establishing antibiotic coverage. With increasing age, the frequency of microorganisms classically referred to as "atypical" (L. pneumophila, Mycoplasma pneumoniae and Chlamydia pneumoniae) decreases and the incidence of Haemophilus influenzae and Gram-negative bacilli increases $[10,20,21]$. In a smaller percentage of the cases, it may be due to viral agents $(12-18 \%)$ and there may be associations of several pathogens (8-14\%) [19]. However, the aetiology of CAP is conditioned by comorbidity, baseline functional status, severity of the acute episode, previously received antimicrobial treatments, contact with the hospital system or place of residence. Therefore, an aetiological approach according to risk factors for resistant microorganisms and severity level is also recommended [22].

In COPD exacerbations, the microorganisms involved vary 


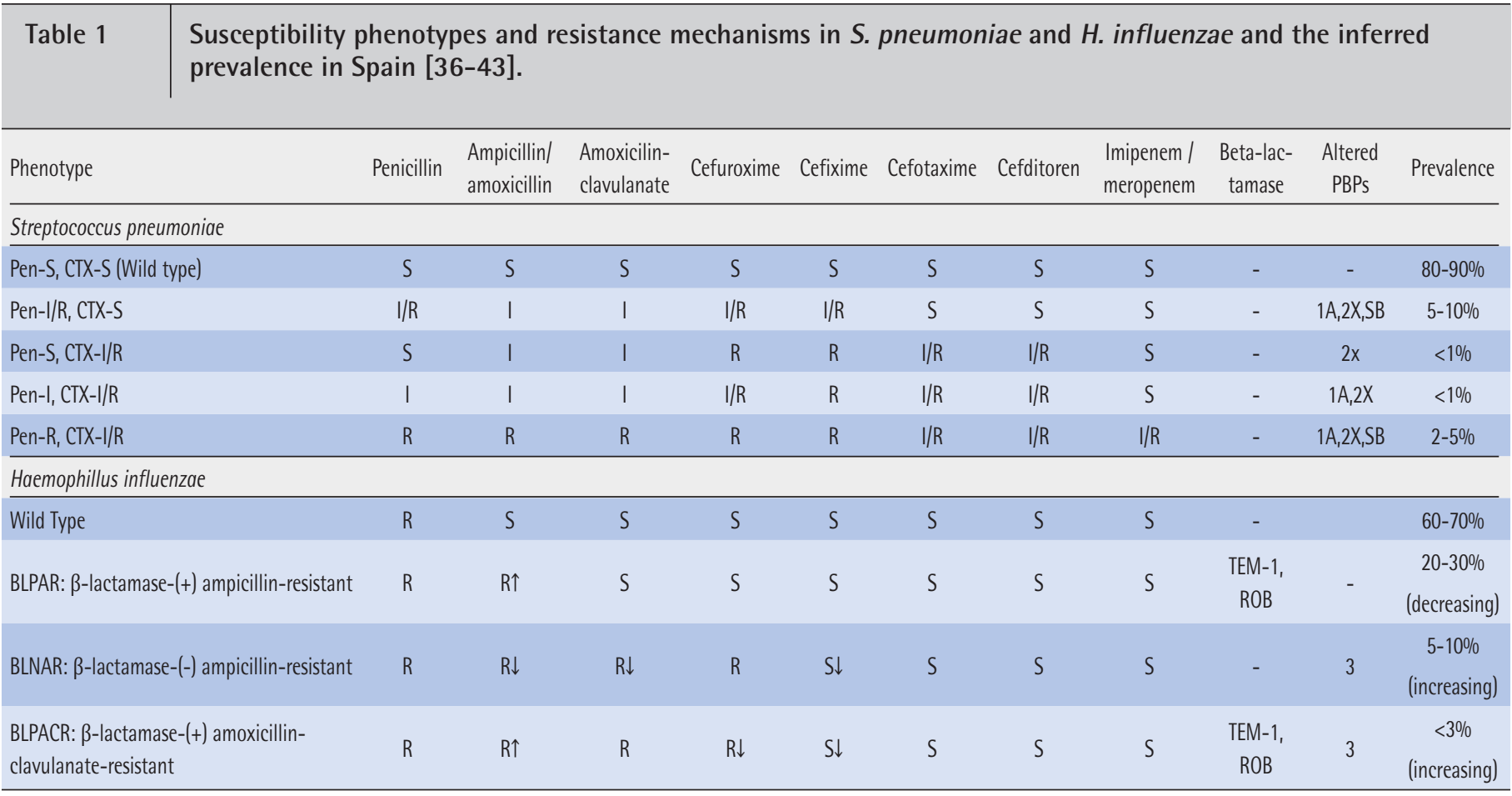

Arrows indicate low ( $\mathrm{R} \downarrow)$ and high level $(\mathrm{R} \uparrow$ ) resistance or decrease susceptibility $(\mathrm{S} \downarrow)$.

according to the type of patient, risk factors and comorbidities. In many cases, they have been named "potentially pathogenic microorganisms" (PPMs) as they can be isolated both in the stable phase and during exacerbations $[23,24]$. H. influenzae is more prominent than in CAP, although $S$. pneumoniae and $M$. catarrhalis may also be present, and to a lesser extent, the socalled "atypicals" [25]. In older patients, Pseudomonas aeruginosa, other Gram-negative bacilli or even Staphylococcus aureus may also be isolated in microbiological cultures, especially in those with bronchiectasis [26]. Anaerobic microorganisms may be detected in COPD, especially in the stable phase. These tend to disappear or become less diverse during exacerbations and have therefore been assigned a protective value against PPM infection [27].

On the other hand, in the antibiotic treatment of CAP, we must try to achieve microbiological eradication, for which it is most convenient to use the most active antibiotics with the highest bactericidal activity against the possible causative pathogens and those that best meet the PK/PD parameters of clinical and microbiological efficacy. In COPD exacerbation, although the therapeutic objective should also be eradication, in practice reduction in the bacterial load is achieved, and a correlation can be established between this reduction and the appearance of a new exacerbation [28]. However, effectiveness, with the aim of achieving maximum microbiological eradication, must be achieved by using the antibiotic with the most restricted spectrum possible to the microorganisms most commonly isolated in this type of infection, in such a way as to minimise antibiotic selection pressure or alterations in the patient's microbiota. Currently, cefditoren, levofloxacin, moxifloxacin and amoxicillin-clavulanic acid in this order have the most appropriate spectrum over the most prevalent pathogens involved in COPD exacerbations and CAP. Moreover, they have also the most relevant PK/PD characteristics in these infections and are therefore included in most antimicrobial treatment guidelines [2,9,16,20,29-35] (Figure 2).

\section{3.- KNOWING THE LOCAL RESISTANCE MAP}

In addition to knowing the possible microorganisms involved in LRTI, it is always necessary to take into account the resistance mechanisms that may be present and to know their frequency at the local level. This will ensure better criteria in the choice of antimicrobial treatment. The latest report of the Instituto de Salud Carlos III, the reference center in Spain, which collects data on resistance of different pathogens, indicates that resistance rates to penicillin and third generation cephalosporins in $S$. pneumoniae have decreased over the years, reaching 21.7\% and 6.0\%, respectively, in 2020 [36]. Resistance to macrolides would be close to $25 \%$, with simultaneous resistance to both compounds estimated at around $12 \%$. These isolates are increasing in some serotypes not included in the thirteen-valent pneumococcal conjugate vaccine $[37,38]$. Surveillance studies conducted in Spain have shown that among oral cephalosporins, cefditoren has a similar behaviour to intravenous third-generation cephalosporins, with higher rates of resistance to cefaclor, cefuroxime and cefixime [39]. Resistance to fluoroquinolones is reported to be less than 2\% [36]. 
Although there are few recent data in Spanish studies, resistance in $\mathrm{H}$. influenzae due to production of beta-lactamases and conferring resistance to amoxicillin, but with sensitivity to amoxicillin-clavulanic acid, has stabilised at around 20-25\%. On the other hand, and as in other countries, resistance to amoxicillin and oral cephalosporins such as cefaclor or cefuroxime, and sometimes to amoxicillin-clavulanic acid, is increasing $[40,41]$. Third-generation cephalosporins, cefotaxime or ceftriaxone, would not be affected, as would cefditoren, which maintains its activity in these isolates [38]. Beta-lactamase-producing strains with altered PBPs and combined resistance to amoxicillin, amoxicillin-clavulanic acid, oral cephalosporins and, to a lesser extent, third-generation cephalosporins, including cefditoren, are also increasing. As in S. pneumoniae, resistance to fluoroquinolones would be scarce and would be present mainly in patients with chronic bronchial infection and extensive exposure to this group of antimicrobials [41-43].

Recent data on $M$. catarrhalis are also scarce, although they indicate a high proportion of isolates with beta-lactamases (TEM or BRO) inhibited by clavulanic acid and low percentages of resistance to macrolides and fluoroquinolones $[44,45]$.

M. pneumoniae is intrinsically resistant to penicillins, with macrolide resistance below 10\%. In contrast, susceptibility to tetracyclines and fluoroquinolones is almost universal in this pathogen [46].

Finally, $P$. aeruginosa is intrinsically resistant to a large number of antimicrobials, narrowing oral therapeutic options to fluoroquinolones. Resistance figures may vary depending on the type of patient, being higher in those with chronic bronchial infection with previous treatment with this group of antimicrobials. In Spain, it would be higher than that found in other countries [47].

Table 1 shows the common susceptibility phenotypes in S. pneumoniae and $H$. influenzae, the associated resistance mechanism and the inferred prevalence of these phenotypes in Spain [36-43].

\section{4.- TO BE QUICK IN ACTION AND EFFECT}

In general, in most infectious syndromes and particularly in LRTI, the efficacy of antimicrobial treatment is fundament in two pillar: 1) control of the microbial inoculum (guided by the antimicrobial chosen) and 2) control of the focus (instrumental or surgical, organic or inorganic biofilm, ...). Derived from both actions, the speed of medical action in the execution of each control strategy and that of the antimicrobial activity translated into its bactericidal effect are essential elements. In fact, infection is an increasingly dynamic process and must be managed as a time-dependent code. In short, "time is money, and time is life".

To achieve these objectives in LRTIs, we must demand that the antimicrobial chosen has two important characteristics: 1) adequate antimicrobial spectrum and 2) optimal antimicrobial potency. Through its ability to cover the microbiological spectrum in an exacerbation of COPD or CAP, we will be sure to have antimicrobial activity against the main aetiological causes of these infectious syndromes, also taking into account the resistance characteristic of these microorganisms (point 3 of the Decalogue). Regarding the antimicrobial potency, we should select those antibiotics with a high activity translated into the ability to eliminate a greater number of microorganisms per unit of time, i.e. to achieve greater inhibition and, if possible, eradication of bacterial inoculum in the shortest possible time.

A bactericidal antibiotic is defined as an antibiotic with the ability to reduce $\geq 3 \log _{10}(99.9 \%) / \mathrm{cfu} / \mathrm{mL}$ of the bacterial inoculum in a given period of time [48]. Examples of this group of antibiotics include beta-lactams, aminoglycosides and fluoroquinolones. Their bactericidal activity is generally determined by so-called lethality or kill curves, which measure the reduction of the bacterial inoculum over time. In general, a bacterial inoculum of $10^{6} \mathrm{cfu} / \mathrm{mL}$ is assumed and the effect is measured over a period of less than 24 hours. An antibiotic is defined as bacteriostatic when the reduction in bacterial inoculum is $<3 \log _{10}$ cfu/mL over a given period of time. Examples of these other antibiotics include, among others, macrolides, clindamycin and tetracyclines. Furthermore, some antibiotics exhibit greater bactericidal activity at a higher dose or concentration of the drug at the site of infection and in a shorter period of time, i.e. the higher the dose of the antibiotic, the greater the bactericidal activity, and the faster as in the case of aminoglycosides. However, others maintain their bactericidal activity independently of the dose or concentration; this is the case of beta-lactams.

Therefore, in CAP and exacerbation of COPD and particularly in elderly patients or with comorbidities, antibiotics with faster action are more adequate $[4,20]$. This feature can improve the prognosis of the patients and avoid complications or sequels. When a comparison of the duration of the comorbidity period is made when compare treatments with antibiotics that achieve rapid decreases in bacterial concentration versus those that only produces slow decreases, the results are in favour of the formers. Antibiotics with high bactericidal capacity have a shorter comorbidity period and, therefore, an earlier and more stable period of normality, in contrast to antibiotics with low bactericidal capacity. This translates into better control of the patient's comorbidity, early clinical stabilisation, and a decrease in the average length of stay and its associated costs $[49,50]$. Late control of infection may even jeopardise patient survival as a result of decompensation of comorbidities.

The bactericidal activity of oral antibiotics used in the treatment of community-acquired LRTIs are clearly different against the main respiratory pathogens (S. pneumoniae, $H$. influenzae and $M$. catarrhalis) $[5,51]$. When comparing several of them (cefuroxime, cefpodoxime, cefixime, amoxicillin-clavulanic acid, cefditoren and levofloxacin), cefditoren and levofloxacin show a greater bactericidal effect in the $\log _{10} \mathrm{cfu} / \mathrm{h}$ reduction curves, both at 4 and 24 hours.

Another relevant aspect in the context of LRTIs is speed of reduction of inflammatory parameters, clinical recovery and 
microbiological eradication [52]. In clinical studies of patients with COPD exacerbations comparing cefditoren versus levofloxacin, the clinical success rate in the overall study population was $78 \%$, with a clinical cure rate of $80 \%$ in the cefditoren group and $75 \%$ in the levofloxacin group [53]. Overall, microbiological eradication in the test of cure was obtained in $85 \%$ of the total study population, although it was slightly higher for levofloxacin compared to cefditoren without statistically significant differences; a higher number of patients with moderate gastrointestinal adverse effects in the levofloxacin-treated group was observed. In addition, inflammatory parameters (such as interleukin-6) were significantly reduced in the test of cure with both cefditoren and levofloxacin compared to the first visit. Although no significant difference, the reduction was higher with cefditoren. The study concluded that this antibiotic represents a valid option in the treatment of mild to moderately severe cases of COPD exacerbation in the outpatient setting, as its use was associated with a significant rapid reduction in interleukin- 6 and other biomarkers of lung inflammation and epithelial damage [53].

The relationship between antimicrobial activity and bactericidal activity is important for all the aspects mentioned above. Moreover, it is relevant for the prevention of selection of resistant strains at the focus of infection, in what would derive from the "fall and rise" theory in the case of COPD or in the avoidance of resistance emergence among the main community respiratory pathogens causing pneumonia through the concept called "selection window" and the "mutant prevention concentration" (MPC) indicator parameter (point 6 of this Decalogue).

\section{5.- ANTIMICROBIAL TOLERANCE AND SAFETY}

The oral antibiotics most commonly used in the treatment of LRTIs can generally be considered safe drugs [8]. Their adverse effects are infrequent and mild and rarely produce irreversible situations in the patients. Knowledge of clinically relevant adverse effects allows for a more judicious use of antibiotics based on the first principle of do no harm, primun non nocere, and the positioning of those that should be included in clinical treatment guidelines as first choice. However, in recent years, concerns have arisen with some of them, in particular fluoroquinolones, due to safety alerts generated by regulatory agencies, relegating them to a secondary position despite their excellent antimicrobial profile against respiratory pathogens associated with COPD exacerbation and CAP $[54,55]$. From a strict safety point of view, it is preferable to initiate treatment with a beta-lactam antibiotic as long as its efficacy is guaranteed according to the expected microorganism. 0therwise, a macrolide or, if appropriate, a fluoroquinolone may be chosen depending on the type and location of the infection and the patient [8]. On which antibiotic to choose within each class, the prioritisation seems clear in the case of beta-lactams, cefditoren over amoxicillin-clavulanic acid, and in the case of macrolides, azithromycin over the others, but it less so in the case of fluoroquinolones.
The adverse effects of antibiotics that affect their safety are due to different mechanisms including direct toxicity, interaction with other drugs, development of resistance and alteration of the microbiota [56]. The latter two are addressed in point 7 of this Decalogue. Toxicity is generally low at approved therapeutic doses and may be due to direct or indirect action on cells or tissues. These include mitochondrial dysfunction leading to organ damage and immunoparalysis. Damage can be caused by dose-dependent pharmacodynamics and pharmacokinetic interactions between the antibiotic and the eukaryotic cells and other drugs respectively, such as cardiac arrhythmias with fluoroquinolones and macrolides and collagen toxicity and neurotoxicity with fluoroquinolones. It is also caused by idiosyncratic immune-mediated reactions similar to anaphylaxis with effects ranging from rashes to toxic epidermal necrolysis or Stevens-Johnson syndrome [57].

Nausea, vomiting and diarrhoea are the most frequent adverse effects of oral antibiotics, but are particularly observed when clavulanic acid is administered at doses above $250 \mathrm{mg} /$ day. As amoxicillin $500 \mathrm{mg}$ and $875 \mathrm{mg}$ tablets available in Spain contain more than $125 \mathrm{mg}$ of clavulanic acid, the usual three-times-daily regimens increase the risk of vomiting and diarrhoea. In addition, amoxicillin-clavulanic acid is considered a hepatotoxic drug and has been associated with genetic variations in the HLA type II system, advanced age and the use of several courses of treatment $[58,59]$. Fluoroquinolones can produce different adverse effects, already discussed above. These are more frequent in patients with specific risk factors for each adverse effect [60] (Table 2).

In relation to interactions with other drugs, they usually occur by modification of their pharmacokinetic properties at different levels that affect absorption, protein binding, metabolism, especially by impact on cytochromes (CYP), elimination or other mechanisms such as serotonergic syndrome in the case of ciprofloxacin [57]. In these cases, there may be a change in the effect of the antibiotic or concomitant drug, which must be assessed in each patient and may require a change of regimen.

\section{6.- MINIMISING TREATMENT DAYS}

The length of an antibiotic treatment plays an important role in the development of antibiotic resistance $[61,62]$. Resistance induction and selection or resistant bacterial population increase with exposure time [61]. The traditional claim that early discontinuation of antibiotic treatment promotes antibiotic resistance is not supported by evidence $[63,64]$. On the contrary, longer duration of antibiotic treatment regimens has been associated with higher rates of resistance as it produces selective pressure not only on potential pathogens but also on microorganisms that are present in the usual microbiota $[62,65]$.

There is evidence to support the safety and efficacy of short versus prolonged antibiotic treatment regimens for most common infections treated in outpatient care $[66,67]$ and in more severe infections treated at the hospital level $[68,69]$. In 


\begin{tabular}{l|l}
\hline Table 2 & $\begin{array}{l}\text { Adverse effects due to fluoroquinolones related to patients at incremental risk } \\
{[61] .}\end{array}$ \\
\hline Adverse effect & Patients at incremental risk \\
\hline OT syndrome & Treatment with non-potassium-sparing diuretics or significant baseline bradycardia \\
\hline Tendonitis & Older age, male, chronic renal disease, corticosteroid use \\
\hline Retinal detachment & Age, past history, cataract surgery \\
\hline Aortic dissection & Age, hypertension, congenital aortic valve anomalies, hereditary connective system disorders \\
\hline Dysglycemias & Advanced age, diabetes, renal insufficiency and concurrent use of hypoglycemic drugs (especially sulphonylureas) \\
\hline Psychiatric effects & Personal or family history \\
\hline
\end{tabular}

\begin{tabular}{l|cc}
\hline Table 3 & $\begin{array}{l}\text { General recommendations of length } \\
\text { period of antimicrobial treatment in } \\
\text { lower respiratory tract infections. }\end{array}$ \\
\hline Infection & Route & Administration \\
\hline Mild & Oral & 5 \\
Moderate/severe & Oral & $5-7$ \\
Severe & Intravenous + oral & 7 (2 intravenous +5 oral) \\
\hline
\end{tabular}

addition, shortening antibiotic time has other advantages such as better adherence, fewer adverse effects and lower cost [65]. Treating bacterial infections for only as long as necessary is probably the safest and most feasible means of reducing unnecessary antibiotic use [70]. The duration of antimicrobial treatment should be individualised and tailored to the clinical response of the patient [71]. Therefore, it should be withdrawn, as soon as possible, once the symptoms of infection are controlled [65]. Table 3 includes general recommendations of duration of antimicrobial treatment in LRTs.

\section{7.- SELECT THE ANTIBIOTIC WITH THE LEAST ANTIMICROBIAL RESISTANCE DEVELOPMENT AND ECOLOGICAL EFFECTS}

The use of antimicrobials should minimise the development of resistance as much as possible. This is achieved with antimicrobials with high bacterial eradication capacity and with treatment schemes that ensure effective concentrations at the focus of infection that exceed the so-called mutant prevention concentration (MPC) that prevents microorganisms from entering in the window of selection $[72,73]$. Also with those that allow to reduce at maximum level the bacterial inoculum at the focus of infection. Treatment with amoxicillin (2 $\mathrm{g} / 12 \mathrm{~h}$ ), cefditoren (400 mg/12 h) or levofloxacin (500 mg/12 h) has a lower risk of selecting for resistance in $S$. pneumoniae than with lower doses of amoxicillin (875/8 h) or levofloxacin
(500 mg/12 h) or with the macrolides or the oral cephalosporins cefuroxime (500 mg/12 h) or cefixime (400 mg/12 h) $[4,74]$ (Figure 3).

Furthermore, regardless of resistance, the antimicrobial chosen must avoid ecological damage to the normal microbiota. This occurs with antimicrobials that do not reduce the socalled "colonisation resistance", a property for which the normal microbiota persists over time on its normal niche despite external aggression or disturbance and also named resiliency. This is generally produced with antimicrobials with minimum or null effect on anaerobic microbiota which are normally those that prevent colonisation of mucosal surfaces with multidrug-resistant bacteria. Several studies have shown that cephalosporins, including those administered by oral route, or amoxicillin have less ecological impact than fluoroquinolones, clindamycin or macrolides, with the usual microbiota recovering more quickly than with the former [75-77]. Fluoroquinolones also have a greater effect on the development of Clostridioides difficile infection than penicillins or cephalosporins $[78,79]$.

\section{8.- ROTATION AND DIVERSIFICATION OF ANTIMICROBIALS}

Antibiotic rotation, understood as the suspension of the use of antimicrobial agents for a certain period of time to be reintroduced later, is not a new concept. It has been used in different clinical settings since the 1950s as one of the strategies proposed to control the emergence of antimicrobial resistance, reduce infection rates or reduce antimicrobial consumption $[80,81]$. This approach aims to reduce the exposure time of bacteria to an antibiotic and thus reduce the selective pressure it exerts on the microbiota of the individual, minimising the emergence of resistance. Several studies have shown that this method is particularly useful in certain clinical departments or patient settings where there is a high use of antimicrobials [82].

On the other hand, diversifying the use of antimicrobials has also been shown to be effective in reducing the emergence and reduction of resistance [83].

In the case of COPD treatment, both strategies are critical 


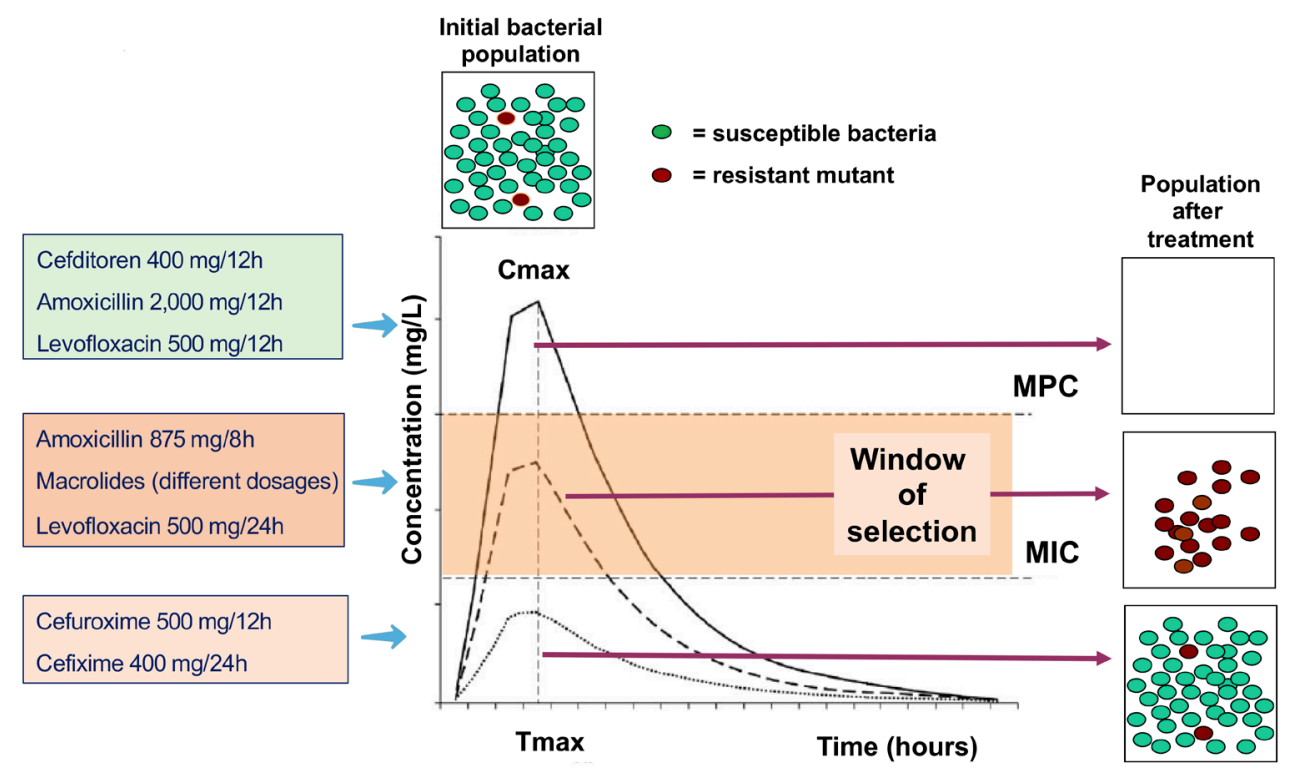

Figure 3 Representation of minimal inhibitory concentration (CMI), mutant selection window and mutant prevention concentration (MPC) over a pharmacokinetic curve of an antimicrobial administered orally and different antimicrobials used in $S$. pneumoniae respiratory tract infections achieving different concentrations [modified from references 4 and 73 ]

to resolve exacerbations. Antimicrobial rotation should include the antimicrobials with most eradication property, so that it effectively contributes to reduce the risk of selection of resistance by decreasing the bacterial burden (quantitative "fall and rise" theory) [6]. It is important to identify the most appropriate antibiotic groups to be rotated in our geographic area, which may vary from one area to another depending on resistance rates. The sequences to be followed in the rotations and the time that should elapse between rotations should also be defined at local level.

In CAP, diversification in antibiotic treatment avoids exerting a high selection pressure and thus spreading strains resistant to that antibiotic [6]. This requires close epidemiological surveillance in the different work settings and insistence on shortening the duration of empirical treatments according to clinical guidelines to reduce antibiotic pressure globally.

\section{9.- SWITCH TO THE ORAL ROUTE AS SOON AS POSSIBLE}

The advantages of implementing sequential therapy are the reduction of antimicrobial treatment costs, the reduced need for accessories and devices for the preparation and administration of the drug (needles, infusion sets, syringes, intravenous solutions, etc), providing the patient with greater comfort, mobility and independence, reducing complications by decreasing the frequency of adverse effects related to intravenous administration, mainly phlebitis and nosocomial infec- tion associated with this route (secondary bacteraemia, septic phlebitis), avoiding the possibility of contracting any type of nosocomial infection associated with a long hospital stay and reducing hospital stay $[84,85]$.

The criteria that patients must meet to proceed with the switch to oral formulation are: heart rate $<100 \mathrm{bpm}$, respiratory rate $<24 \mathrm{rpm}$, axillary temperature below $37.2^{\circ} \mathrm{C}$, systolic blood pressure $>90 \mathrm{mmHg}$, oxygen saturation $>90 \%$, good level of consciousness and tolerance to the oral route [86].Regarding the selection of the appropriate oral antimicrobial, this should be done in the same way as the intravenous depending on the possible expected aetiology (causative microorganism), local sensitivity and resistance patterns, PK/PD characteristics of each antibiotic and the epidemiological situations and particular characteristics of the patient (age, comorbidity, contraindications, allergic history, etc.).

Table 4 shows the equivalence of antimicrobials for establishing sequential therapy in patients with COPD exacerbations or CAP. In the case of amoxicillin-clavulanic acid and fluoroquinolones, there are galenic presentations of the same antibiotic for both routes. However, in the case of amoxicillin-clavulanic acid, it should be considered that the change from intravenous dosing to the available oral formulation (875mg/125mg) implies a decrease in the dose of amoxicillin, which would fall within the mutant selection window, and an increase in clavulanic acid, so it may also be appropriate to perform sequential therapy with another beta-lactam such as cefditoren. In the case of third generation intravenous cepha- 


\section{\begin{tabular}{l|l} 
Table 4 & Equivalence of antimicrobials for
\end{tabular} sequential therapy in patients with COPD exacerbations or CAP}

\begin{tabular}{ll}
\hline Intravenous treatment & Oral treatment \\
\hline Amoxicillin-clavulanate & Amoxicillin-clavulanate or cefditoren \\
\hline Fluoroquinolone & Fluoroquinolones \\
\hline Macrolides & Macrolides \\
Cefotaxime or ceftriaxone & Cefditoren \\
\hline
\end{tabular}

losporins, the most appropriate sequential therapy is cefditoren due to the fact that it has a similar spectrum and intrinsic activity [4].

\section{0.- KEEPING UP TO DATE: CONSULT THE ANTIMICROBIAL TREATMENT GUIDELINES}

Along with proven experience and practical common sense, knowledge based on scientific evidence is a third key element in the competence of healthcare and/or research doctors. They must try to keep up to date with scientific knowledge. The increased volume of information, together with the changing dynamism of the results of studies and trials, and their interpretations, makes difficult to manage the acquisition and assimilation of knowledge. In addition to the modern and fragile express assertions of a multitude of social networks, a more rigorous and controlled way is to consult clinical practice guidelines, consensus documents and recommendations made by methodologists and experts in each subject under the umbrella of official agencies or scientific societies.

The objectives of a clinical guideline, such as those on LRTIs, should be to improve the appropriateness of empirical antibiotic treatment, reduce uncertainty and medical errors, assist in decision-making, improve adherence to protocols, reduce and optimise the use of antimicrobials, allow for shorter treatment durations and/or stays, help control the selection of resistant bacteria and reduce costs. Other functions that an international, national or local guidelines may include are serving as a reference standard or criterion for quality and appropriateness of treatments in programmes for antimicrobial stewardship, keeping knowledge up to date by compiling new evidence on the approach to infections (diagnostic criteria, pharmacological and non-pharmacological recommendations according to patient characteristics and severity of the process. Moreover, they are tools for shared decision-making with the patient and for training activities.

The guidelines must be constantly updated, consult the appropriate sources, rigorously analyse the results of the studies selected and evaluated, and offer comparative exposition of these results with respect to the considered recommendations that will be offered in the guideline. Failure to do so may result in the opposite ending with outdated antibiotic treat- ment indications that do not include all available options, that do not establish appropriate dosages and precise duration of treatment, or that even show doubt or confusion.

In the case of guidelines for the selection of oral antibiotics in LRTIs, in addition to international guidelines, there are good and sufficient national guidelines and expert documents available in Spain [4-8,20,16,30-35,87-89]. In these ones, we have indications for antimicrobial treatment in two major respiratory infectious syndromes: exacerbation of COPD and outpatient CAP. For both entities, a classification is established from mild to severe, or risk factors for specific microorganisms that require a more special or selected antimicrobial therapy (e.g. of P. aeruginosa) or by age and underlying comorbidities. Based on this, different scenarios or risk factors are cross-referenced with the main microorganisms causing infection, priority indications for empirical antibiotic treatment are given and other alternative options are listed (Table 5) [34].

In turn, with regard to the antibiotics available and recommended for the oral treatment of LRTIs, the guidelines show which antibiotics are available, to which class or families they belong, their spectrum of microorganisms included according to their mechanism of action and intrinsic activity and, of course, comparative assessments are established in relevant aspects such as safety and tolerance, drug interactions and risk of dysbiosis due to alteration of the microbiome, all translated in a practical way, for example, into the risk of causing infection by $C$. difficile.

Of the classes of antimicrobials included and assessed in these guidelines, for classical respiratory bacterial pathogens (such as S. pneumoniae, H. influenzae and M. catarrhalis), the beta-lactam family stands out especially in their indication, distancing them from the fluoroquinolone family for several reasons, one of them being the safety, tolerance and pharmacological interactions, with a better profile for the former and with pharmacological alerts indicating toxicity problems and complications with the latter.

However, not all beta-lactams have the same characteristics and behave in the same way, and some of the guidelines go so far as to comparatively dissect the different oral options in this family: aminopenicillin and beta-lactamase inhibitor combination (such as amoxicillin-clavulanic acid) or second (cefuroxime axetil) and third generation cephalosporins (cefixime and cefditoren). In turn, clear differences can be established between the cephalosporins themselves, as some of them may show a lack of sufficient or optimal intrinsic activity against Gram-positive microorganisms (pneumococci), as is the case for cefixime or ceftibuten, or offer only a deficient and suboptimal concentration achieved in the lung at the dose marketed or indicated in the summary of product characteristics (such as cefuroxime), making some of these beta-lactam options less advisable than other third-generation oral cephalosporins (cefditoren), which are more recommended for community respiratory pathology.

In addition, not all guidelines include other relevant as- 


\section{Table 5}

Oral antimicrobials recommended in mild or moderate COPD exacerbations and community acquired pneumonia [34]

\begin{tabular}{|c|c|c|c|}
\hline & \multirow[b]{2}{*}{ Microorganisms } & \multicolumn{2}{|c|}{ Empiric antibiotics* } \\
\hline & & First choice & Alternative \\
\hline \multicolumn{4}{|l|}{ COPD exacerbation (COPD-E) } \\
\hline \multirow[t]{3}{*}{ Mild } & H. influenzae & Amoxicillin-clavulanate $875-125 \mathrm{mg} / 8 \mathrm{~h} 5-7$ days & Levofloxacin ${ }^{\complement} 500 \mathrm{mg} / 24 \mathrm{~h}, 5-7$ days \\
\hline & S. pneumoniae & Cefditoren $400 \mathrm{mg} / 12 \mathrm{~h}, 5$ days & Moxifloxacin ${ }^{\mathrm{c}} 400 \mathrm{mg} / 24 \mathrm{~h}, 5-7$ days \\
\hline & M. catarrhalis & & \\
\hline \multirow{3}{*}{$\begin{array}{l}\text { Moderate without risk factors } \\
\text { for } P \text {. aeruginosa }\end{array}$} & H. influenzae & Amoxicillin-clavulanate $875-125 \mathrm{mg} / 8 \mathrm{~h} 5-7$ days & Levofloxacin ${ }^{\complement} 500 \mathrm{mg} / 24 \mathrm{~h}, 5-7$ days \\
\hline & S. pneumoniae & Cefditoren $400 \mathrm{mg} / 12 \mathrm{~h}, 5$ days & Moxifloxacin ${ }^{\mathrm{c}} 400 \mathrm{mg} / \mathrm{d}, 5-7$ days \\
\hline & M. catarrhalis + Pen-R S. pneumoniae & & \\
\hline \multirow{2}{*}{$\begin{array}{l}\text { Moderate with risk factors } \\
\text { for } P \text {. aeruginosa }\end{array}$} & P. aeruginosa & Ciprofloxacin $750 \mathrm{mg} / 12 \mathrm{~h}, 5-7$ days & \\
\hline & & Levofloxacin $500 \mathrm{mg} / 12 \mathrm{~h}, 5-7$ days & \\
\hline \multicolumn{4}{|l|}{ Community acquired pneumonia (CAP) } \\
\hline \multirow{3}{*}{$\begin{array}{l}\text { Non severe CAP in }<65 \text { years, without } \\
\text { significant chronic morbidity or without risk } \\
\text { factors for infection with Gram-negatives } \\
\text { or Legionella spp, irrespective of aetiological } \\
\text { suspicion }\end{array}$} & S. pneumoniae & Amoxicillin $1 \mathrm{~g} / 8 \mathrm{~h}, 5-7$ days & Cefditoren ${ }^{\mathrm{a}} 400 \mathrm{mg} / 12 \mathrm{~h}, 5$ days \\
\hline & H. influenzae & & Levofloxacinc $500 \mathrm{mg} / \mathrm{d}, 5-7$ days \\
\hline & M. pneumoniae & & Moxifloxacin ${ }^{\mathrm{c}} 400 \mathrm{mg} / \mathrm{d}, 5-7$ days \\
\hline \multirow{4}{*}{$\begin{array}{l}\text { Non severe CAP in }<65 \text { years, with } \\
\text { significant chronic morbidity or other risk } \\
\text { factors for infection with Gram-negatives }\end{array}$} & S. pneumoniae & Amoxicillin-clavulanic $875-125 \mathrm{mg} / 8 \mathrm{~h} \mathrm{5-7}$ days & Levofloxacin ${ }^{\mathrm{C}} 500 \mathrm{mg} / \mathrm{d}, 5-7$ dias \\
\hline & H. influenzae & + macrolide $^{b}$ & Moxifloxacin ${ }^{\mathrm{c}} 400 \mathrm{mg} / \mathrm{d}, 5-7$ dias \\
\hline & K. pneumoniae / other enterobacterial & Cefditoren $^{a} 400 \mathrm{mg} / 12 \mathrm{~h}, 5$ dias $+/$ - macrolide ${ }^{b}$ & \\
\hline & Legionella spp & & \\
\hline \multirow[t]{3}{*}{ CAP in COPD } & S. pneumoniae & Amoxicilin-clavulanate $875-125 \mathrm{mg} / 8 \mathrm{~h} \mathrm{5-7}$ days & \\
\hline & H. influenzae & $+\mid-$ macrolide $^{b}$ & \\
\hline & M. pneumoniae & Cefditoren $^{\mathrm{a}} 400 \mathrm{mg} / 12 \mathrm{~h}, 5$ dias & \\
\hline
\end{tabular}

*Dosing regimen correspond to current Spanish recommendations included in the guidelines and not that included in the summary of product characteristics:

alt should be prescribed if there is documented penicillin allergy or if the patient has been previously treated with amoxicillin or amoxicillin-clavulanate

${ }^{b}$ Add a macrolide (azithromycin $500 \mathrm{mg} / 24$ h, 3 days or clarithromycin $500 \mathrm{mg} / 12,7$ days) if there are risk factor or suspicion of L. pneumophila infection

'Only recommended when a macrolide is not possible

pects, such as: a) some third-generation oral cephalosporins with sufficient intrinsic activity against the most common respiratory pathogens, with comfortable dosage and good safety profile (e.g. cefditoren) are considered first line treatment option, particularly in patients older than 65 years. Moreover, it should be prescribed if a course of treatment with amoxicillin or amoxicillin-clavulanic acid has been used in the previous three months; b) the addition of a macrolide (azithromycin $500 \mathrm{mg} /$ day, oral for three days or clarithromycin $500 \mathrm{mg} / 12 \mathrm{~h}$ for seven days) should be considered if there are epidemiological risk factors or clinical suspicions of acquiring and developing infection with L. pneumophila or other "atypical" microorganisms and cannot be ruled out by rapid microbiological tests and c) use of fluoroquinolones only when beta-lactams cannot be used or when there is a need to cover certain microorganisms such as Gram-negative bacilli with resistance mechanisms, e.g. P. aeruginosa.
Finally, the inclusion of a given antimicrobial family globally or an antibiotic in particular in an oral antibiotic treatment guideline for LRTIs should be made on the basis of good tolerance profile, low capacity for selection of resistance mechanisms and minimal ecological impact, even assuming equal efficacy. Overall, beta-lactams have these characteristics and exceed the fluoroquinolone family in efficacy and tolerance, which are included as alternatives in LRTI guidelines and which have safety alerts by regulatory agencies $[54,55]$. The inclusion in these guidelines of certain third-generation oral cephalosporins, such as ceftditoren, with high efficacy and recognised tolerance, since they are not all the same, also helps to diversify the use of antibiotics, one of the pillars to minimise the selection of resistant and multiresistant bacteria. This is a key objective in the programmes to combat antimicrobial resistance and antimicrobial stewardship. 


\section{CONCLUSIONS}

The selection of oral antibiotics in LRTI should be based on knowledge of the bacterial aetiology and the frequency of local antimicrobial resistance, preferably those with a rapid mode of action, which achieve the greatest effect in the shortest time and with the fewest adverse effects (toxicity, interactions, resistance and/or ecological impact). Whenever possible, rotate and diversify antimicrobials and switch to the oral route as soon as possible. This Decalogue is intended as an aid to prescribing oral treatment for mild to moderate exacerbations of COPD and CAP. The concepts contained in this Decalogue are also contemplate in clinical treatment guideless.

\section{CONFLICTS OF INTEREST}

This manuscript has been written exclusively by the undersigned authors as part of an educational program funded by Meiji Pharma Spain, S.A. RC has participated in educational programs sponsored by Chiessi and Zambon. MS has participated in educational programs or given lectures sponsored by Angelini, Gilead, MSD and Pfizer. JGC received research grants, consultant/speaker honoraria as well as financial support for educational programs of his department from Thermofisher, Meiji, GlaxoSmithKline, Gilead, Roche, and Angelini. Other authors do not declare conflicts of interest

\section{REFERENCES}

1. Dekker AR, Verheij TJ, van der Velden AW. Inappropriate antibiotic prescription for respiratory tract indications: most prominent in adult patients. Fam Pract. 2015;32:401-7. doi: 10.1093/fampra/ cmv019.

2. González del Castillo J, Candel FJ, de la Fuente J, Gordo F, MartínSánchez FJ, Menéndez $R$, et al. Manejo integral del paciente con exacerbación aguda de la enfermedad pulmonar. Rev Esp Quimioter. 2018; 31(5):461-484. PMID: 30284414.

3. Fernández-Urrusuno $R$, Meseguer Barros $C M$, Anaya-Ordóñez $S$, Borrego Izquierdo $Y$, Lallana-Álvarez MJ, Madridejos $\mathrm{R}$, et al. Patients receiving a high burden of antibiotics in the community in Spain: a cross-sectional study. Pharmacol Res Perspect. 2021; 9(1):e00692. doi: 10.1002/prp2.692.

4. Menéndez R, Cantón R, Garcia-Caballero A, Barberán J. Tres claves para seleccionar el antibiótico oral adecuado en las infecciones respiratorias. Rev Esp Quimioter. 2019; 32:497-515. PMID: 31795630.

5. Cantón R. Aspectos microbiológicos actuales de la infección respiratoria comunitaria más allá de la COVID-19. Rev Esp Quimioter. 2021; 34:81-92. doi: 10.37201/req/049.2021.

6. González del Castillo J, Julián-Jiménez A, Candel FJ. Neumonía comunitaria: selección del tratamiento empírico y terapia secuencial. Implicaciones del SARS-CoV-2. Rev Esp Quimioter. 2021; 34:599609. doi: $10.37201 / \mathrm{req} / 144.2021$.

7. Rodríguez González-Moro JM, Izquierdo Alonso JL. Tratamiento antibiótico oral de la exacerbación de la EPOC. Más allá de la
COVID-19. Rev Esp Quimioter. 2021; 34:429-40. doi:10.37201/ req/125.2021.j.

8. Barberán J, Barberán LC, de la Cuerda A. Seguridad en la selección del tratamiento antibiótico oral en las infecciones comunitarias, más allá de la COVID-19. Rev Esp Quimioter. 2021; 34:289-97. doi: 10.37201/req/087.202.

9. Clinical Practice Guideline for the Diagnosis and Treatment of Patients with Chronic Obstructive Pulmonary disease (COPD) - the Spanish COPD Guideline (GesEPOC). 2017 Version Working group of the GesEPOC Arch Bronconeumol 2017; 53(Supl 1):2-64. doi: 10.1016/j.arbres.2017.03.018.

10. Torres A, Cilloniz $C$, Niederman MS, Menéndez $R$, Chalmers JD, Wunderink RG, et al. Pneumonia. Nat Rev Dis Primers. 2021 Apr 8;7(1):25. doi:10.1038/s41572-021-00259-0.

11. Mathioudakis AG, Chatzimavridou-Grigoriadou $V_{1}$ Corlateanu A, Vestbo J. Procalcitonin to guide antibiotic administration in COPD exacerbations: a meta-analysis. Eur Respir Rev. 2017. doi: 10.1183/16000617.0073-2016.

12. Jones B, Waterer G. Advances in community-acquired pneumonia. Ther Adv Infect Dis. 2020 Nov 6;7:2049936120969607. doi: $10.1177 / 2049936120969607$.

13. Ito $A$, Ishida T. Diagnostic markers for community-acquired pneumonia. Ann Transl Med. 2020 May;8(9):609. doi: 10.21037| atm.2020.02.182.

14. Anthonisen NR, Manfreda J, Warren $C P$, Hershfield ES, Harding GK,Nelson NA. Antibiotic therapy in exacerbations of chronic obstructive pulmonary disease. Ann Intern Med. 1987;106:196-204. doi:10.7326/0003-4819-106-2-196

15. Miravitlles M, Moragas A, Hernández S, Bayona C, Llor C. Is it possible to identify exacerbations of mild to moderate COPD that do not require antibiotic treatment? Chest. 2013; 44:1571-7. doi: 10.1378/ chest.13-0518

16. Soler-Cataluña JJ, Piñera P, Trigueros JA, Calle M, Casanova C, Cosío BG, et al. Spanish COPD Guidelines (GesEPOC) 2021 Update Diagnosis and Treatment af COPD Exacerbation Syndrome. Arch Bronconeumol. 2021 May 26:S0300-2896(21)00166-6. doi: 10.1016/j. arbres.2021.05.011.

17. Soler N, Agusti C, Angrill J, Puig de la Bellacasa J, Torres A. Bronchoscopic validation of the significance of sputum purulence in severe exacerbations of chronic obstructive pulmonary disease. Thorax. 2007; 62:29-35. doi: 10.1136/thx.2005.056374.

18. Woodhead M, Blasi F, Ewig S, Garau J, Huchon G, leven M, Ortqvist A, Schaberg T, Torres A, van der Heijden G, Read R, Verheij TJ; Joint Taskforce of the European Respiratory Society and European Society for Clinical Microbiology and Infectious Diseases. Guidelines for the management of adult lower respiratory tract infections--full version. Clin Microbiol Infect. 2011; 17 (Suppl 6):E1-59. doi: 10.1111/j.1469-0691.2011.03672.x.

19. Jain $S$, Self WH, Wunderink RG, Fakhran $S$, Balk R, Bramley AM, et al. Community-acquired pneumonia requiring hospitalization among U.S. Adults. N Engl J Med. 2015; 373:415-27. doi: 10.1056/ NEJMoa1500245.

20. González-Castillo J, Martín-Sánchez FJ, Llinares P, Menéndez R, 
Mujal A, Navas $E_{1}$ et al. Guidelines for the management of community-acquired pneumonia in the elderly patient. Rev Esp Quimioter. 2014; 27:69-86. PMID: 24676248.

21. Carugati M, Aliberti S, Sotgiu G, Blasi F, Gori A, Menendez R, et al. Bacterial etiology of community-acquired pneumonia in immunocompetent hospitalized patients and appropriateness of empirical treatment recommendations: an international point-prevalence study. Eur J Clin Microbiol Infect Dis. 2020; 39:1513-25.

22. Shorr AF, Zilberberg MD, Reichley R, Kan J, Hoban A, Hoffman J, et al. Validation of a clinical score for assessing the risk of resistant pathogens in patients with pneumonia presenting to the emergency department. Clin Infect Dis. 2012; 54:193-8. doi: 10.1093/cid/ cir813.

23. Lopez-Campos JL, Miravitlles $M$, de la Rosa Carrillo D, Cantón R, Soler-Cataluña JJ, Martinez-Garcia MA. Current challenges in chronic bronchial infection in patients with chronic obstructive pulmonary disease. J Clin Med. 2020 May 28;9(6):1639. doi: 10.3390/jcm9061639.

24. Ditz B, Christenson S, Rossen J, Brightling C, Kerstjens HAM, van den Berge M, Faiz A. Sputum microbiome profiling in COPD: beyond singular pathogen detection. Thorax. 2020; 75:338-44. doi: 10.1136/thoraxjnl-2019-214168.

25. Welp AL, Bomberger JM. Bacterial community interactions during chronic respiratory disease. Front Cell Infect Microbiol. 2020 May 14; 10:213. doi: 10.3389/fcimb.2020.00213.

26. Garcia-Clemente $M$, de la Rosa $D$, Máiz L, Girón R, Blanco M, Olveira

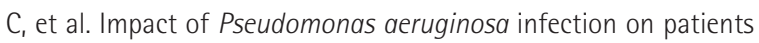
with chronic inflammatory airway diseases. J Clin Med. 2020 24; 9(12):3800. doi: 10.3390/jcm9123800.

27. Caverly $\sqcup$, Huang YJ, Sze MA. Past, present, and future research on the lung microbiome in inflammatory airway disease. Chest. 2019; 156:376-82. doi:10.1016/j.chest.2019.05.011.

28. Miravitlles $M_{1}$ Anzueto A. Chronic respiratory infection in patients with chronic obstructive pulmonary disease: What is the role of antibiotics? Int J Mol Sci. 2017 Jun 23;18(7):1344. doi: 10.3390/ ijms18071344.

29. Julián-Jiménez $A$, Adán Valero I, Beteta López A, Cano Martín LM, Fernández Rodríguez 0, Rubio Díaz R, et al. Recomendaciones para la atención del paciente con neumonía adquirida en la comunidad en los Servicios de Urgencias. Rev Esp Quimioter. 2018; 31:186202. PMID: 29619807;

30. Menéndez R, Cilloniz C, España, Almiralle J, Uranga U, Méndez R, Rigauf $R$, Torres A. Community-Acquired Pneumonia. Spanish Society of Pulmonology and Thoracic Surgery (SEPAR) Guidelines. 2020 Update. Arch Bronconeumol. 2020; 56 (Suppl 1):1-10. doi: 10.1016/j. arbres.2020.01.014.

31. Julián-Jiménez A. Manual de protocolos y actuación en urgencias. 5a Edición, 2021 (https://toledo.sanidad.castillalamancha.es/sites/ toledo.sescam.castillalamancha.es/files/publicaciones/08/07/2021/ manual_de_urgencias.pdf)

32. InfurgSEMES. Guía de antibioterapia empírica en infecciones prevalentes 2021 (http://www.infurg-semes.org/)

33. Mensa J, Soriano A, López-Suñé E, Llinares $P$, Barberán J, Zboro- myrska Y. Guia de terapéutica antimicrobiana. Ed. 2021. Editorial ANTARE. ISBN: 9788488825339.

34. Molero JM, Azcoaga A, Muñoz J. Los principales problemas en salud: Infecciones frecuentes en atención primaria (I). AMF 2021; 17(3):124-33. Disponible: https://amf-semfyc.com/web/article/2904

35. Guia de uso de antimicrobianos en adultos con tratamiento ambulatorio v3. Madrid: Consejería de Sanidad, Servicio Madrileño de Salud; diciembre 2021. Disponible en: https://www.comunidad.madrid/publicacion/ref/50515

36. Memoria (2020) de la red de vigilancia EARS-Net. Resultados de los hospitales españoles participantes en la Red. European Antimicrobial Resistance Surveillance Network. https://www.isciii.es/ QuienesSomos/CentrosPropios/CNM/ResistenciasAntibacterianas/ Investigacion/SiteAssets/Paginas/OtrosResultados/Memoria\%20 EARS-Net-2020.pdf

37. Fernández-Delgado L, Càmara J, González-Díaz A, Grau I, Shoji H, Tubau F, et al. Martí S, Serotypes in adult pneumococcal pneumonia in Spain in the era of conjugate vaccines. Microorganisms. 2021 Oct 28;9(11):2245. doi: 10.3390/microorganisms9112245.

38. Fenoll A, Granizo JJ, Giménez MJ, Yuste J, Aguilar L. Secular trends (1990-2013) in serotypes and associated non-susceptibility of $S$. pneumoniae isolates causing invasive disease in the pre-/post-era of pneumococcal conjugate vaccines in Spanish regions without universal paediatric pneumococcal vaccination. Vaccine. 2015; 33:5691-9. doi:10.1016/j.vaccine.2015.08.009.

39. Giménez MJ, Aguilar L, Granizo JJ. Revisiting cefditoren for the treatment of community-acquired infections caused by human-adapted respiratory pathogens in adults. Multidiscip Respir Med. 2018 Nov 2;13:40. doi: 10.1186/s40248-018-0152-5.

40. García-Cobos $S$, Arroyo M, Pérez-Vázquez M, Aracil B, Lara N, Oteo $J$, et al. Isolates of -lactamase-negative ampicillin-resistant Haemophilus influenzae causing invasive infections in Spain remain susceptible to cefotaxime and imipenem. J Antimicrob Chemother. 2014; 69:111-6. doi: 10.1093/jac/dkt324.

41. Carrera-Salinas A, González-Díaz A, Calatayud L, Mercado-Maza J, Puig C, Berbel D, et al. Epidemiology and population structure of Haemophilus influenzae causing invasive disease. Microb Genom. 2021; 7(12). doi: 10.1099/mgen.0.000723.

42. Domenech A, Tirado-Vélez JM, Fenoll A, Ardanuy C, Yuste J, Liñares $J$, et al. Fluoroquinolone-resistant pneumococci: dynamics of serotypes and clones in Spain in 2012 compared with those from 2002 and 2006. Antimicrob Agents Chemother. 2014; 58:2393-9. doi: 10.1128/AAC.02669-13.

43. Puig C, Tirado-Vélez JM, Calatayud L, Tubau F, Garmendia J, Ardanuy $C_{1}$ et al. Molecular characterization of fluoroquinolone resistance in nontypeable Haemophilus influenzae clinical isolates. Antimicrob Agents Chemother. 2015; 59:461-6. doi: 10.1128/AAC.04005-14.

44. Canton R. Resistance trends in Moraxella catarrhalis (PROTEKT years 1-3 [1999-2002]). J Chemother. 2004 Dec;16 Suppl 6:63-70. doi:10.1080/1120009x.2004.11782403.

45. Kyd JM, McGrath J, Krishnamurthy A. Mechanisms of bacterial resistance to antibiotics in infections of COPD patients. Curr Drug 
Targets. 2011; 12(4):521-30. doi: 10.2174/138945011794751519.

46. Waites KB, Xiao L, Liu Y, Balish MF, Atkinson TP. Mycoplasma pneumoniae from the respiratory tract and beyond. Clin Microbiol Rev. 2017; 30:747-809. doi: 10.1128/CMR.00114-16.

47. Martinez-Garcia MA, de la Rosa D, Cantón R, Olveira C, Máiz-Carro $L$, Girón $R$, et al. Bronchiectasis: when the published scientific evidence proves Insufficient. Arch Bronconeumol. 2019; 55:283-5. doi: 10.1016/j.arbres.2019.05.001.

48. Peterson $L R$, Shanholtzer $C J$. Tests for bactericidal effects of antimicrobial agents: technical performance and clinical relevance. Clin Microbiol Rev. 1992; 5:420-32. doi: 10.1128/CMR.5.4.420.

49. González del Castillo J et al. Gestión del arsenal antibiótico. Monografias Emergencias, 2014, vol. 8; n²:1-8.

50. García-Lamberechts EJ, González-Del Castillo J, Hormigo-Sánchez Al, Núñez-Orantos MJ, Candel FJ, Martín-Sánchez FJ. Factores predictores del fracaso al tratamiento antibiótico empírico. An Sist Sanit Navar. 2017;40(1):119-130. doi: 10.23938/ASSN.0011. PMID: 28534544.

51. Barberan J, Cantón R, Menéndez R, Calleja MA, Gonzalez del Castillo J, Díaz $\mathrm{S}$, et al. El valor de Cefditoreno en la infección respiratoria. Disponible en: http://www.infurg semes.org/PDF/Cefditoreno_monografico.pdf

52. Mezzatesta ML, Gona F, Marchese G, Nicolosi D, Toscano MA, Stefani $S$, et al. Cefditoren versus community-acquired respiratory pathogens: time-kill studies. J Chemother. 2009; 21:378-82. doi: 10.1179/joc.2009.21.4.378.

53. Di Marco F, Braido F, Santus P, Scichilone N, Blasi F. The role of cefditoren in the treatment of lower community-acquired respiratory tract infections (LRTIs): from bacterial eradication to reduced lung inflammation and epithelial damage. Eur Rev Med Pharmacol Sci. 2014; 18:321-32. PMID: 24563430.

54. Blasi F, Tarsia P, Mantero M, Morlacchi LC, Piffer F. Cefditoren versus levofloxacin in patients with exacerbations of chronic bronchitis: serum inflammatory biomarkers, clinical efficacy, and microbiological eradication. Ther Clin Risk Manag. 2013; 9: 55-64. doi: 10.2147/TCRM.S41131.

55. Food and Drugs Administration. FDA Drug Safety Communication: FDA advises restricting fluoroquinolone antibiotic use for certain uncomplicated infections; warns about disabling side effects that can occur together https://www.fda.gov/drugs/drug-safety-and-availability/fda-drug-safety-communication-fda-advises-restricting-fluoroquinolone-antibiotic-use-certain (accessed January 5, 2022)

56. European Medicines Agency. Disabling and potentially permanent side effects lead to suspension or restrictions of quinolone and fluoroquinolone antibiotics. https://www.ema.europa.eu/en/documents/referral/quinolone-fluoroquinolone-article-31-referral-disabling-potentially-permanent-side-effects-lead_en.pdf (accessed January 5, 2022)

57. Arulkumaran N, Routledge M, Schlebusch S, Lipman J, Conway Morris A. Antimicrobial associated harm in critical care: a narrative review. Intensive Care Med 2020; 46:225-235. doi.org/10.1007/ s00134-020-05929-3.
58. Pai MP, Momary KM; Rodvold KA. Antibiotic drug interactions. Med Clin North Am 2006; 90:1223-55. doi: 10.1016/j.mcna.2006.06.008.

59. White AR, Kaye C, Poupard J, Pypstra R, Woodnutt G, Wynne B. Augmentin (amoxicillin/clavulanate) in the treatment of community-acquired respiratory tract infection: a review of the continuing development of an innovative antimicrobial agent. J Antimicrob Chemother 2004; 53(Suppl 1):i3-i20. doi: 10.1093/jac/ dkh050.

60. Lagace-Wiens $P$, Rubinstein E. Adverse reactions to beta-lactam antimicrobials. Expert Opin Drug Saf. 2012; 11:381-399. doi: 10.1517/14740338.2012.643866

61. Tandan M, Cormican M, Vellinga A. Adverse events of fluoroquinolones vs. other antimicrobials prescribed in primary care: $\mathrm{A}$ systematic review and me- ta-analysis of randomized controlled trials. Int J Antimicrob Agents. 2018 52:529-40. doi: 10.1016/j.ijantimicag.2018.04.014.

62. Pasquau J, Matesanz M. Duración del tratamiento antibiótico. Rev Esp Quimioter. 2015; 28 (Suppl 1):30-3. PMID: 26365731.

63. Giacomini E, Perrone V, Alessandrini D, Paoli D, Nappi C, Degli Esposti L. Evidence of antibiotic resistance from population-based studies: A narrative review. Infect Drug Resist. 2021; 14:849-58. doi: 10.2147/IDR.S289741.

64. Del Mar C, Looke DFM. Should we abandon "finishing the course" of antimicrobials? BMJ. 2017 Sep 22; 358:j4170. doi: 10.1136/bmj. j4170.

65. Llewelyn MJ, Fitzpatrick JM, Darwin E, SarahTonkin-Crine, Gorton C, Paul J, et al. The antibiotic course has had its day. BMJ. $2017 \mathrm{Jul}$ 26;358:j3418. doi: 10.1136/bmj.j3418.

66. Spellberg B. The maturing antibiotic mantra: "Shorter is still better". J Hosp Med. 2018 May 1; 13(5):361.362. doi: 10.12788/jhm.2904.

67. Dawson-Hahn EE, Mickan S, Onakpoya I, Roberts N, Kronman M, Butler CC, et al. Short-course versus long-course oral antibiotic treatment for infections treated in outpatient settings: a review of systematic reviews. Fam Pract. 2017; 34:511-9. doi: 10.1093/ fampra/cmx037.

68. Palin V, Welfare W, Ashcroft DM, van Staa TP. Shorter and longer courses of antibiotics for common infections and the association with reductions of infection-related complications including hospital admissions. Clin Infect Dis. 2021; 73:1805-12. doi: 10.1093/ cid/ciab159.

69. Royer S, DeMerle KM, Dickson RP, Prescott HC. Shorter versus longer courses of antibiotics for infection in hospitalized patients: A systematic review and meta-analysis. J Hosp Med. 2018; 13:336342. doi: 10.12788/jhm.2905.

70. Smith BJ, Heriot G, Buising K. Antibiotic treatment of common infections: more evidence to support shorter durations. Curr Opin Infect Dis. 2020; 33:433-40. doi:10.1097/0C0.0000000000000680.

71. Wald-Dickler N, Spellberg B. Short-course antibiotic therapy-replacing constantine units with "shorter is better". Clin Infect Dis. 2019; 69:1476-9. doi: 10.1093/cid/ciy1134.

72. Lee RA, Centor RM, Humphrey LL, Jokela JA, Andrews R, Qaseem A, et al. Appropriate use of short-course antibiotics in common infections: best practice advice from the American College of Physicians. Ann Intern Med. 2021; 174:822-7. doi: 10.7326/M20-7355. 
73. Cantón R, Morosini MI. Emergence and spread of antibiotic resistance following exposure to antibiotics. FEMS Microbiol Rev. 2011; 35:977-91. doi: 10.1111/j.1574-6976.2011.00295.x

74. Sethi S, Anzueto A, Miravitlles M, Arvis P, Alder J, Haverstocky D et al. Determinants of bacteriological outcomes in exacerbations of chronic obstructive pulmonary disease. Infection, 2016; 44:65-76. doi: 10.1007/s15010-015-0833-3.

75. Giménez MJ, Aguilar L, Granizo JJ. Revisiting cefditoren for the treatment of community-acquired infections caused by human-adapted respiratory pathogens in adults. Multidiscip Respir Med. 2018 Nov 2;13:40. doi: 10.1186/s40248-018-0152-5.

76. Sullivan A, Edlund C, Nord CE. Effect of antimicrobial agents on the ecological balance of human microflora. Lancet Infect Dis. 2001; 1:101-14.

77. Jernberg C, Löfmark S, Edlund C, Jansson JK. Long-term impacts of antibiotic exposure on the human intestinal microbiota. Microbiology. 2010; 156(Pt 11):3216-3223. doi: 10.1099/ mic.0.040618-0.

78. Zimmermann $\mathrm{P}$, Curtis $\mathrm{N}$. The effect of antibiotics on the composition of the intestinal microbiota - a systematic review. J Infect. 2019;79(6):471-489. doi: 10.1016/j.jinf.2019.10.008.

79. Vardakas KZ, Trigkidis KK, Boukouvala E, Falagas ME. Clostridium difficile infection following systemic antibiotic administration in randomised controlled trials: a systematic review and meta-analysis. Int J Antimicrob Agents. 2016; 48:1-10. doi: 10.1016/j.ijantimicag.2016.03.008.

80. Wilcox MH, Chalmers JD, Nord CE, Freeman J, Bouza E. Role of cephalosporins in the era of Clostridium difficile infection. J Antimicrob Chemother. 2017; 72:1-18. doi: 10.1093/jac/dkw385.

81. Gerding DN, Larson TA, Hughes RA, Weiler M, Shanholtzer C, Peterson LR. Aminoglycoside resistance and aminoglycoside usage: ten years of experience in one hospital. Antimicrob Agents Chemother. 1991; 35:1284-90. doi:10.1128/AAC.35.7.1284.

82. Goulart CP, Mahmudi M, Crona KA, Jacobs SD, Kallmann M, Hall $B G$, et al. Designing antibiotic cycling strategies by determining and understanding local adaptive landscapes. PLOS One. 2013; 8(2):e56040. doi: 10.1371/journal.pone.0056040.

83. John JF Jr, Rice LB. The microbial genetics of antibiotic cycling. Infect Control Hosp Epidemiol. 2000; 21(1 Suppl):S22-31. doi: 10.1086/503170.

84. Cobos-Trigueros N, Solé M, Castro P, Torres JL, Rinaudo M, De Lazzari $E_{1}$ et al. Evaluation of a mixing versus a cycling strategy of antibiotic use in critically-ill medical patients: impact on acquisition of resistant microorganisms and clinical outcomes. PLoS One. 2016; 11(3):e0150274. doi: 10.1371/journal.pone.0150274.

85. Candel FJ, Julián-Jiménez A, González-Del Castillo J. Current status in outpatient parenteral antimicrobial therapy: a practical view. Rev Esp Quimioter. 2016; 29:55-68. PMID: 27014770.

86. Ramos Lázaro J, Chico $C$, Jove N, Blázquez Fernández $A B$, Fernández Monasterio MM, Smithson A. Tratamiento antimicrobiano domiciliario endovenoso en hombres con infección del tracto urinario febril: diferencias entre el modelo de evitación de ingreso y el de alta precoz hospitalaria. Emergencias. 2021; 33:399-402. PMID: 34581537.
87. Halm EA, Fine MJ, Marrie TJ, Coley CM, Kapoor WN, Obrosky DS, et al. Time to clinical stability in patients hospitalized with community-acquired pneumonia: implications for practice guidelines. JAMA. 1998; 279:1452-7. doi: 10.1001/jama.279.18.1452

88. Menéndez R, Torres A, Aspa J, Capelastegui A, Prat C, Rodríguez de Castro F. Neumonía adquirida en la comunidad. Nueva normativa de la Sociedad Española de Neumología y Cirugía Torácica (SEPAR). Arch Bronconeumol. 2010; 46(10):543-58. doi: 10.1016/j. arbres.2010.06.014.

89. Miravitlles M, Soler-Cataluña JJ, Calle M, Molina J, Almagro P, Quintano JA, et al. Spanish Guidelines for Management of Chronic Obstructive Pulmonary Disease (GesEPOC) 2017. Pharmacological Treatment of Stable Phase. Arch Bronconeumol. 2017; 53(6): 32435. doi: 10.1016/j.arbres.2017.03.018.

90. González del Castillo J, Candel FJ, de la Fuente J, Gordo F, MartínSánchez FJ, Menéndez R, et al. Manejo integral del paciente con exacerbación aguda de la enfermedad pulmonar. Rev Esp Quimioter. 2018; 31:461-84. PMID: 30284414. 